\title{
Neutropenia-monocytopenia-deafness syndrome
}

INSERM

\section{Source}

INSERM. (1999). Orphanet: an online rare disease and orphan drug data base.

Neutropenia-monocytopenia-deafness syndrome. ORPHA:2690

Neutropenia-monocytopenia-deafness syndrome is characterised by neutropenia with myeloid marrow hypoplasia, monocytopenia, and congenital deafness. It has been described in three siblings who suffered recurrent bacterial infections. 